\title{
PERANAN ARBITRASE (BASYARNAS) DALAM PENYELESAIAN SENGKETA BISNIS SYARI'AH
}

\author{
Dr. Eko Siswanto, M.HI. \\ Institut Agama Islam Negeri (IAIN) Fattahul Muluk, Papua \\ Email : siswantoeko44@yahoo.co.id
}

\begin{abstract}
Basyarnas as the agency authorized to settle business disputes Shari'ah has a very important role, including: resolving disputes with the principle of prioritizing civil peace efforts; resolving disputes over business operations using Islamic law can be resolved with the use of Islamic law; resolve the possibility of civil disputes between banks Shari'ah with customers or users of their services in particular, and among Muslims who perform civil relationships that make Islamic shari'ah as essentially in general is a genuine need real; and provide a simply and speedy settlement of disputes in civil muamalah or arising in the field of trade, industry, services and others. Basyarnas dispute settlement through confidence and security will be guaranteed for the parties to the dispute; the expertise of the arbitrators; arbitration is confidential; wisdom and sensitivity arbitrator; arbitration decisions more easily implemented than justice; rapid and cost-effective completion. The various stages of settlements, namely: a request to conduct the arbitration; Determination Arbiter; examination; peace; evidence and witnesses or experts; the end of the examination; decision making; improvement of the decision; cancellation of the decision; registration decision; implementation of the decision; and arbitration costs.
\end{abstract}

Keywords: Basyarnas, Dispute, Islam.

\begin{abstract}
Abstrak
Basyarnas merupakan lembaga yang memiliki wewenang untuk menangani sengketa masalah bisnis Syariah memiliki peran yang penting termasuk menyelesaikan masalah dengan perdamaian, menyelesaikan masalah bisnis menggunakan hukum islam yang bisa diselesaikan dengan hukum islam, menyelesaikan sengketa antara masyarakat dan bank syariah sebagai nasabah atau pengguna jasa, dan antara muslim yang mengadakan perjanjian yang membuat Hukum Islam sebagai kebutuhan dasar, dan menyediakan penyelesaian secara sederhana terhadap penyelesaian muamalah atau perdagangan, industri, servis, dan lainnya. Jaminan penyelesaian sengketa oleh Basyaranas diselesaikan secara rahasia dan tertutup, arbiter yang tidak memihak, putsan arbitrase lebih mudah diimplementasikan daripada keadilan, cepat dan relatif murah. Adapun tahapan penyelesaiannya yaitu: permohonan untuk melaksanakan arbitrase, menetukan arbiter, penjelasan, bukti, dan pernyataan dari para pihak, akhir pemeriksaan, pembuatan keputusan, pengingkatan keputusan, membatalkan putusan, mendaftarkan putusan, pelaksanaan putusan, dan pembayaran arbitrase.
\end{abstract}

Kata Kunci : Basyarnas, Sengketa, Islam 


\section{PENDAHULUAN}

Abu' al-Hakam pada masa Nabi dihormati karena kebijaksanaannya dalam menangani setiap perselisihan anggota masyarakat yang diajukan kepadanya. Kemudian di jaman khalifah Umar bin Khattab keberadaan hukum telah berkembang dengan berbagai upaya perbaikan terhadap sistem peradilan. Dalam hal ini, perihal hukum telah termuat dalam risalah al-Qada yang di dalamnya sekaligus memuat kedudukan arbitrase.

Lembaga arbitrase (hakam) telah dikenal sejak zaman Islam. Pada masa itu masih belum terdapat sistem peradilan yang terorganisir dengan baik. suatu contoh jika ada persoalan mengenai hak milik, hak waris dan hak-hak lainnya, saat itu masih diselesaikan dengan bantuan juru damai yang ditunjuk oleh masing-masing pihak yang berselisih. ${ }^{1}$ Suatu misal, sebelum Muhammad menerima tugas kerasulan, beliau pernah bertindak sebagai wasit pada perselisihan diantara sesama suku Quraisy tentang orang yang tepat untuk bertugas meletakkan kembali Hajar Aswad pada posisi semula. Kebijakan Nabi untuk menyelesaikan perselisihan tentang Hajar Aswad ini diterima secara sukarela oleh pihak-pihak yang bersengketa waktu itu.

Sedangkan pada masa sekarang, di era globalisasi, ciri perekonomian yang paling menonjol adalah serba cepat yang mendorong manusia memasuki apa yang dimaksud Free Market dan Free Competition. Kondisi yang demikian tersebut, jika melihat sekian banyak transaksi bisnis yang ada, tidak mungkin dihindari terjadinya perselisihan yang menghendaki penyelesaian secara cepat dan tepat. Hal ini sesuai dengan lingkup kewenangan Badan Arbitrase Syari'ah Nasional (BASYARNAS) sebagai lembaga yang memiliki kewenangan untuk menyelesaikan permasalahan secara cepat dan tepat terhadap permasalahan perdata (muamalah) yang disebabkan oleh berbagai bentuk kerjasama dibidang muammalah yang menurut ketentuan hukum dan peraturan perundang-undangan dikuasai sepenuhnya oleh pihak yang bersengketa. Adapun para pihak yang melakukan kesepakatan bahwa persoalannya diselesaikan di BASYARNAS harus secara tertulis untuk menyerahkan penyelesaiannya kepada BASYARNAS sesuai dengan prosedur serta memberikan pendapat yang mengikat atas permintaan para pihak tanpa adanya suatu sengketa mengenai persoalan berkenaan dengan suatu perjanjian.

${ }^{1}$ N.J. Coulson, A History of Islamic Law (New York: Edinberg University Press, 1991), h. 10. 
Tradisi penyelesaian sengketa melalui juru damai lebih berkembang pada masyarakat Makkah yang notabene sebagai pusat perdagangan. Untuk menangani sengketa para pihak yang berhubungan dengan ganti rugi serta persoalan akibat praktek-praktek bisnis, selain di Makkah, perwasitan juga berkembang pada masyarakat Madinah sebagai daerah agraris untuk menangani masalah-masalah sengketa hak milik atas tanah. ${ }^{2}$

Di zaman Nabi, beliau sebagai sosok pembawa ajaran Islam telah mentradisikan mediasi atau perwasitan tersebut dikembangkan dengan menghilangkan praktik-praktik menyimpang dari aqidah Islam. Langkah Nabi ini sesuai dengan cara dakwah Nabi bahwa tidak semua tradisi sebelum Islam di dakwahkan dihapus secara total, tetapi tetap dibiarkan berlangsung dengan secara perlahan-lahan disesuaikan dengan aturan-aturan Islam sehingga ajarannya bersifat kompromis dengan tetap berpijak pada landasan aqidah Islamiah yang kokoh.

Dengan bergesernya waktu, tentu saja tata cara dan proses penyelesaian sebuah sengketa pun juga akan berubah. Misalnya, proses atau cara penyelesaian sengketa bisnis yang saat ini sedang popular adalah arbitrase. Istilah arbitrase berasal dari kata arbitrare (bahasa Latin) yang berarti kekuasaan untuk menyelesaikan sesuatu menurut kebijaksanaan. Dihubungkannya arbitrase dengan kebijaksanaan itu dapat menimbulkan salah pengertian tentang arbitrase karena dapat menimbulkan kesan seolah-olah seorang arbiter atau suatu majelis arbitrase dalam menyelesaikan suatu sengketa tidak mengindahkan norma-norma hukum lagi dan menyandarkan pemutusan sengketa tersebut hanya pada kebijaksanaan. Kesan tersebut keliru karena arbiter atau majelis tersebut juga menerapkan hukum seperti yang dilakukan oleh hakim atau pengadilan.

Proses atau tata cara penyelesaian sengketa melalui arbitrase, dalam prakteknya sudah lama dikenal di Indonesia. Bahkan sebelum kemerdekaan pun penyelesaian sengketa lewat arbitrase ini sudah ada dan dikenal, misalnya dalam

${ }^{2}$ Warkum Sumitro, Asas-Asas Perbankan Islam dan Lembaga-Lembaga Terkait (BMI dan di Indonesia) (Jakarta: PT RajaGrafindo Persada, 2002), h. 151. Selain menjadi wasit dalam perkara Hajar Aswat, Nabi juga sering menjadi wasit dalam sengketa-sengketa umatnya. Misalnya Ka'bah Ibn Malik dan Ibn Abi Hadrad, pada waktu itu Nabi bertindak sebagai wasit tunggal. Namun setelah perkembangan wilayah Islam semakin meluas beliau memberikan delegasi wewenang kepada para sahabatnya untuk menjadi wasit, misalnya kepada Sa'id Ibn Muaz dalam perselisihan antara Umar dengan Ubay Ibn Ka'ab tentang kasus Nahl dan kasus-kasus lainnya. 
bidang perburuhan dikenal penyelesaian perselisihan perburuhan lewat arbitrase. Dalam bidang perdagangan, setelah kemerdekaan ada beberapa badan arbitrase tetap yang didirikan oleh berbagai perkumpulan dan organisasi perdagangan di Indonesia yang sekarang tentu saja tidak aktif lagi. Badan-badan arbitrase yang dimaksudkan itu adalah badan arbitrase yang didirikan oleh:

1.Organisasi Eksportir Hasil Bumi Indonesia di Jakarta;

2.Organisasi Asuransi Kebakaran Indonesia di Jakarta;

3.Organisasi Kecelakaan Indonesia di Jakarta.

Dengan mencermati bahwa begitu pentingnya peran lembaga arbitrase dalam penyelesaian sengkete para pihak terutama dalam permasalah bisnis dan perdagangan, serta terbatasnya pengetahuan warga tentang lembaga arbitrase, maka perlu kiranya lewat tulisan ini dibahas tentang "Peran Arbitrase (BASYARNAS) Dalam Penyelesaian Sengketa Bisnis Syari'ah”.

\section{SEJARAH DAN DASAR HUKUM BERDIRINYA BASYARNAS}

\section{Sejarah Berdirinya Basyaranas}

Arbitrase Syari'ah di Indonesia bermula dari Rapat Kerja Nasional (Rakernas) MUI tahun 1992, Hartono Marjono, SH, ditugasi menyampaikan konsepnya tentang arbitrase berdasarkan syari'at Islam yang kemudian mendapat sambutan baik dari kalangan peserta dan kamudian direkomendasikan untuk ditindak lanjuti oleh MUI. Pada tanggal 22 April 1992 Dewan Pimpinan MUI mengundang praktisi hukum termasuk kalangan perguruan tinggi guna bertukar pikiran tentang perlu tidaknya dibentuk arbitrase Islam. Pada pertemuan tanggal 2 Mei 1992, diundang juga dari bank muamalat Indonesia yang selanjutnya dibentuk tim khusus guna mempersiapkan bahan-bahan kajian untuk melihat peluang membentuk badan arbitrase Islam.

Demikian selanjutnya dalam Rakernas MUI 24-27 November 1992 yang memutuskan bahwa sehubungan dengan rencana pendirian Lembaga Arbitrase Muamalat, agar MUI segera merealisasikan. MUI dengan SK. No. Kep. 392/MUI/V/1992, tanggal 4 mei 1992 membentuk kelompok kerja pembentukan badan arbitrase hukum Islam, yang terdiri dari: 1. Prof. KH. Ali Yafie; 2. Prof KH. Ibrahim Husen, LML; 3. H. Andi Lolo Tonang, S.H; 4. H. Hartono Mardjono, S.H; 5. Jimly Asshiddiqie, SH,MH. sebagai narasumber. 
Badan Arbitrase Syariah Nasional pada saat didirikan bernama Badan Arbitrase Muamalat Indonesia (BAMUI). BAMUI yang didirikan pada tanggal 21 Oktober 1993 berbadan hukum yayasan. Akte pendiriannya ditandatangani oleh Ketua MUI K.H. Basri dan Sekretaris Umum HS. Prodjokusumo. BAMUI dibentuk oleh MUI berdasarkan Rapat Kerja Nasional (Rakernas) MUI Tahun 1992. Perubahan nama dari BAMUI menjadi BASYARNAS diputuskan dalam Rakernas MUI tahun 2002. Perubahan nama, perubahan bentuk dan pengurus BAMUI dituangkan dalam SK. MUI No. Kep-09/MUI/XII/2003 Tanggal 24 Desember 2003. Ketetapan yang di ambil dalam SK tersebut yakni:

a.Mengubah nama Badan Arbitras Mu'amalat Indonesia (BAMUI) menjadi BASYARNAS.

b.Mengubah bentuk badan BAMUI dari yayasan menjadi badan yang berada di bawah MUI dan merupakan perangkat organisasi.

c.Dalam melaksanakan tugas dan fungsinya sebagai lembaga hakam, BASYARNAS bersifat otonom.

\section{Dasar Hukum Berdirinya Basyarnas}

a. Q.S. Al-Nisa /4: 35:

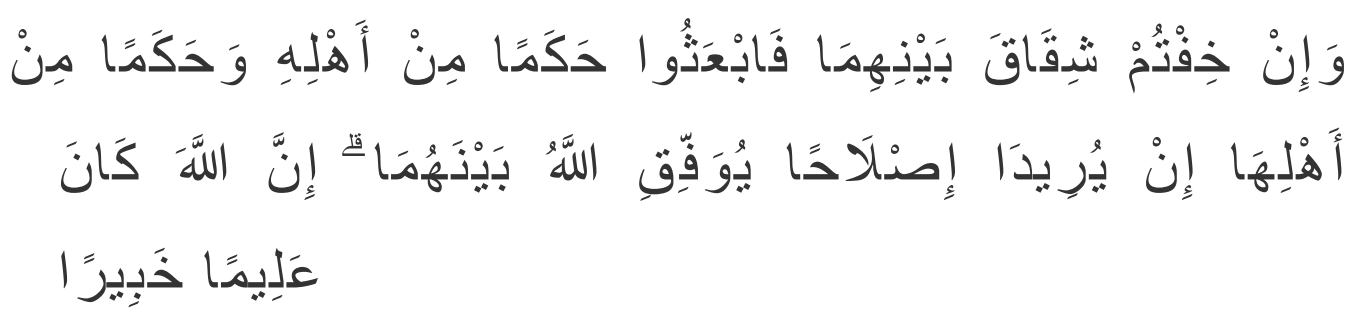

Terjemahnya: Dan jika kamu khawatirkan ada persengketaan antara keduanya, Maka kirimlah seorang hakam dari keluarga laki-laki dan seorang hakam dari keluarga perempuan. jika kedua orang hakam itu bermaksud Mengadakan perbaikan, niscaya Allah memberi taufik kepada suami-isteri itu. Sesungguhnya Allah Maha mengetahui lagi Maha Mengenal.

b. Q.S. al-Hujurat/49: 9:

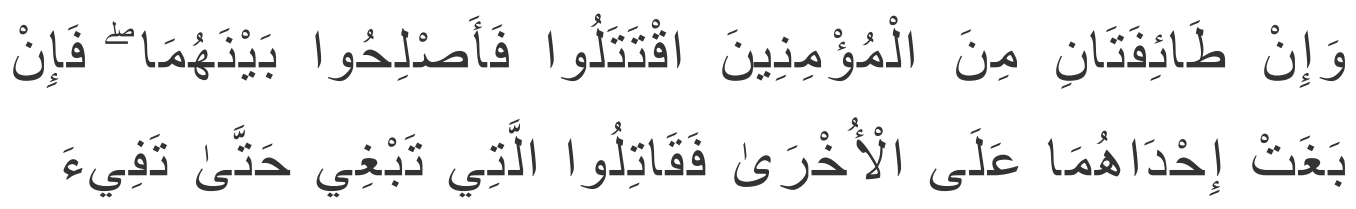




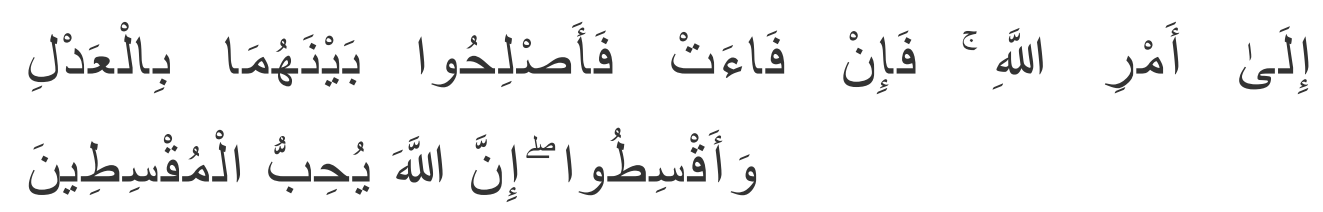

Terjemahnya: Dan kalau ada dua golongan dari mereka yang beriman itu berperang hendaklah kamu damaikan antara keduanya! tapi kalau yang satu melanggar Perjanjian terhadap yang lain, hendaklah yang melanggar Perjanjian itu kamu perangi sampai surut kembali pada perintah Allah. kalau Dia telah surut, damaikanlah antara keduanya menurut keadilan, dan hendaklah kamu Berlaku adil; Sesungguhnya Allah mencintai orang-orang yang Berlaku adil.

c. As-Sunnah: Hadis riwayat An-Nasa'i menceritakan dialog Rasulullah dengan Abu Syureih. Rasulullah bertanya kepada Abu Syureih: "Kenapa kamu dipanggil Abu Al-Hakam?” Abu Syureih menjawab: "Sesungguhnya kaumku apabila bertengkar, mereka datang kepadaku, meminta aku menyelesaikannya, dan mereka rela dengan keputusanku itu”. Mendengar jawaban Abu Syureih itu Rasulullah berkata: "Alangkah baiknya perbuatan yang demikian itu". Demikian Rasulullah membenarkan bahkan memuji perbuatan Abu Syureih, Sunnah yang demikian disebut Sunnah Taqririyah.

d. Ijma': Adanya riwayat menunjukkan bahwa para ulama dan sahabat Nabi sepakat membenarkan penyelesaian sengketa dengan cara arbitrase. Misalnya, diriwayatkan tatkala Umar bin Khat $\}$ t $\} a>b$ hendak membeli seekor kuda. Pada saat Umar menunggang kuda itu untuk uji coba, kaki kuda itu patah. Umar hendak mengembalikan kepada pemiliknya, namun pemilik kuda itu menolak. Umar berkata: "Baiklah, tunjuklah seseorang yang kamu percayai untuk menjadi arbiter (hakam) antara kita berdua. Pemilik kuda berkata: "Aku rela Abu Syureih untuk menjadi hakam". Maka keduanya menyerahkan penyelesaian sengketa itu kepada Abu Syureih. Abu Syureih (hakam) yang dipilih itu memutuskan bahwa Umar harus mengambil dan membayar harga kuda itu. Abu Syureih berkata kepada Umar bin Khattab: “Ambillah apa yang kamu beli (dan bayar harganya) atau kembalikan kepada pemilik apa yang telah kamu ambil seperti semula tanpa cacat”. Umar menerima baik putusan itu.

e. Undang-Undang No. 30 Tahun 1999 tentang Arbitrase dan Alternatif Penyelesaian Sengketa. Arbitrase menurut undang-undang no. 30 tahun 1999 
merupakan mekanisme penyelesaian sengketa perdata diluar peradilan umum, sedangkan lembaga arbitrase adalah badan yang dipilih oleh para pihak yang bersengketa untuk memberikan putusan mengenai sengketa itu. Badan Arbitrase Syari'ah Nasional adalah lembaga arbitrase sebagaimana dimaksud UU. No. 30/1999.

f. SK. MUI. SK Dewan Pimpinan MUI No. Kep-09/MUI/XII/2003 Tanggal 30 Syawwal 1424 H (24 Desember 2003) tentang Badan Arbitrase Syari'ah Nasional.

g. Fatwa DSN-MUI. Semua fatwa Dewan Syari'ah Nasional Majelis Ulama Indonesia (DSN-MUI) perihal hubungan perdata (muamalah) senantiasa diakhiri dengan ketentuan: "Jika salah satu pihak tidak menunaikan kewajibannya atau jika terjadi perselisihan diantara kedua belah pihak, maka penyelesaiannya dilakukan melalui Badan Arbitrase Syari'ah setelah tidak tercapai kesepakatan melalui musyawarah. (Lihat Fatwa No. 05 tentang jual beli saham, Fatwa No. 06 tentang jual beli istisna, Fatwa No. 07 tentang pembiayaan mudarabah, Fatwa No. 08 tentang pembiayaan musyarakah, dan seterusnya).

\section{PENGERTIAN, ASAS DAN TUJUAN BASYARNAS}

\section{Pengertian Basyarnas}

Badan Arbitrase Syariah Nasional (BASYARNAS) merupakan badan yang dapat menyelesaikan sengketa perdata atau muamalat Islam dengan memutuskan suatu keputusan hukum atas masalah yang dipersengketakan dengan cara tahki $>m$. Di sisi lain, BASYARNAS juga dapat menyelesaikan perkara perdata lainnya sepanjang tidak bertentangan dengan undang-undang yang berlaku. Keputusan yang ditetapkan oleh BASYARNAS terhadap perkara yang diajukan kepadanya bersifat binding (mengikat) dan final (tidak ada banding atau kasasi). Pembatalan keputusan arbitrase dapat dilakukan sesuai dengan Undang-Undang No. 30 tahun 1999 tentang arbitrase dan alternatif penyelesaian sengketa. Ketentuan syarat-syarat arbiter dan penyelesaian sengketa perdata atau muamalah Islam melalui BASYARNAS dimaksudkan untuk meningkatkan kinerja lembaga tersebut pada masa yang akan datang. Di samping itu untuk meningkatkan profesionalisme, kerahasiaan para pihak yang bersengketa, 
kearifan dan kepekaan aribter, dan kecepatan serta efesiensi biaya bagi penyelesaian sengketa harus diperhatikan. Kehadiran BASYARNAS di harapkan dapat dirasakan peranannya bagi masyarakat dalam menyelesaikan berbagai sengketa dengan jalan damai (islah) dan tetap terjalinnya ukhuwah antara para pihak yang bersengketa.

Di sisi lain, istilah arbitrase berasal dari Bahasa Belanda: "arbitrate" dan Bahasa Inggris: arbitration, dalam Bahasa Latin: arbitrare, yang berarti penyelesaian atau pemutusan sengketa oleh seorang atau beberapa hakim berdasarkan persetujuan bahwa mereka akan tunduk dan mentaati keputusan yang diberikan oleh hakim atau para hakim yang mereka pilih atau tunjuk tersebut. Arbitrase merupakan suatu peradilan perdamain, dimana para pihak yang bersengketa atau berselisih menghendaki perselisihan mereka tentang hak-hak pribadi yang dapat mereka kuasai sepenuhnya, diperiksa dan diadili oleh hakim yang adil yaitu tidak memihak kepada salah satu pihak yang berselisih tersebut. Keputusan arbitrase mengikat bagi kedua belah pihak. Dalam pasal 1 ayat 1 Undang-Undang No. 30 tahun 1999 tentang Arbitrase dan Alternatif Penyelesaian Sengketa, bahwa yang dimaksud dengan arbitrase adalah cara penyelesaian suatu sengketa perdata di luar peradilan umum yang didasarkan pada perjanjian arbitrase yang dibuat secara tertulis oleh para pihak yang bersengketa.

Guna mendapatkan pemahaman mengenai arbitrase, ada pendapat beberapa sarjana dan peraturan perundang-undangan serta prosedur Badan Arbitrase yang ada telah memberikan definisi arbitrase sebagai berikut:

a.Arbitrase menurut Subekti adalah penyelesaian atau pemutusan sengketa oleh seorang hakim atau para hakim berdasarkan persetujuan bahwa para pihak akan tunduk pada atau manaati keputusan yang diberikan oleh hakim yang mereka pilih. ${ }^{3}$

b.Arbitrase menurut H. priyatna Abdurrasyid adalah suatu proses pemeriksaan sengketa yang dilakukan secara yudisial sebagaimana dikehendaki oleh para pihak yang bersengketa, dan pemecahannya akan didasarkan kepada buktibukti yang diajukan oleh para pihak. ${ }^{4}$

\footnotetext{
${ }^{3}$ Subekti, Arbitrase Perdagangan (Bandung: Bina Cipta, 1992), h. 1.

${ }^{4}$ Priyatna Abdurrasyid, Penyelesaian Sengketa Komersial (Nasional dan Internasionalo di Luar Pengadilan, Makalah, September 1996, h. 1
} 
c.Arbitrase (perwasitan) menurut H.M.N. Poerwosutjipto adalah suatu peradilan perdamaian, di mana para pihak bersepakat agar perselisihan mereka tentang hak pribadi yang dapat mereka kuasai sepenuhnya diperiksa dan diadili oleh hakim yang tidak memihak yang ditunjuk oleh para pihak sendiri dan putusannya mengikat bagi kedua belah pihak. ${ }^{5}$

d.Frank Elkoury dan Edna Elkoury menyatakan bahwa arbitrase merupakan proses yang mudah atau simple yang dipilih oleh para pihak secara sukarela yang ingin agar perkaranya diputus oleh juru pisah yang netral sesuai dengan pilihan mereka di mana keputusan berdasarkan dalil-dalil dalam perkara tersebut. Para pihak setuju sejak semula untuk menerima putusan tersebut secara final dan mengikat. ${ }^{6}$

e.Menurut UU No. 30 Tahun 1999 tentang Arbitrase dan Alternatif Penyelesaian Sengketa Umum, Pasal 1 huruf 1, arbitrase adalah cara penyelesaian suaatu sengketa perdata di luar peradilan umum yang didasarkan pada perjanjian arbitrase yang dibuat secara tertulis oleh para pihak yang bersengketa.

Menurut peraturan prosedur Badan Arbitrase Nasional Indonesia, arbitrase adalah memberikan penyelesaian yang adil dan cepat dalam sengketa-sengketa perdata yang timbul mengenai perdagangan, industry, keuangan, baik yang bersifat nasional maupun internasional. (Pasal 1 AD BANI).

Prosedur BAMUI (Badan Arbitrase Muammalat Indonesia) sebagai lembaga arbitrase merupakan penyelesaian sengketa yang timbul dalam hubungan perdagangan, industri, keuangan, jasa dan lain-lain, serta memberikan suatu pendapat yang mengikat tanpa adanya suatu sengketa mengenai suatu persoalan yang berkenaan dengan perjanjian. (Pasal 1 AD BAMUI).

Berbagai pengertian arbitrase di atas menunjukkan adanya unsur-unsur yang sama, yaitu: pertama, adanya kesepakatan untuk menyerahkan penyelesaian

5 H.M.N. Poerwosutjipto, Pokok-Pokok Hukum Dagang, Perwasitan, Kepailitan dan Penundaan Pembayaran Cet. III (Jakarta: Djambatan, 1992), h.1.

${ }^{6}$ Frank Elkory dan Edna Elkoury, How Arbitration Work, Washington DS., 1974, dikutip dari M. Husseyn dan A. Supriyani Kardono, Kertas Kerja Hukum Ekonomi, Hukum dan Lembaga Arbitrase di Indonesia, (Jakarta: Proyek Pengembangan Hukum Ekonomi dan penyempurnaan Sistem Pengadaan, Kantor Menteri Negara Koordinasi Bidang Ekonomi, Keuangan dan Pengawasan Pengembangan, 1995), h. 2. 
sengketa-sengketa, baik yang akan terjadi maupun yang telah terjadi, kepada seorang atau beberapa orang pihak ketiga di luar peradilan umum untuk diputuskan; kedua, penyelesaian sengketa yang bias diselesaikan adalah sengketa yang menyangkut hak pribadi yang dapat dikuasai sepenuhnya, khususnya di sini dalam bidang perdagangan, industri dan keuangan; dan ketiga, putusan tersebut akan merupakan putusan akhir dan mengikat (final and binding).

Meskipun ada kesamaan unsur-unsur yang terkandung dari pengertian yang dikemukakan para sarjana di atas, namun penggunaan istilahnya ada yang berbeda. Misalnya H.M.N. Poerwosutjipto menggunakan istilah perwasitan untuk arbitrase dan wasit untuk arbiter. Sedangkan Subekti tetap menggunakan istilah arbitrase, namun arbiternya digunakan istilah hakim. Dalam beberapa literatur dijumpai juga penggunaan istilah lain, seperti "Van der Tass" menggunakan istilah wasit/juru pemisah/perantara untuk arbiter, dan perwasitan/pemisah sukarela untuk arbitrase. ${ }^{7}$ Soekardono menggunakan istilah wasit untuk arbiter, dan peradilan wasit untuk arbitrase. $^{8}$ Sunaryati Hartono menggunakan istilah wasit untuk arbiter, dan perwasitan untuk arbitrase. ${ }^{9}$ Berkaitan dengan berbagai istilah tersebut, berikutnya akan digunakan istilah arbitrase dan arbiter karena secara yuridis istilah ini sudah diakui dan atau digunakan oleh Undang-Undang No. 30 Tahun 1999 tentang Arbitrase dan Alternatif Penyelesaian Sengketa Umum.

\section{Asas dan Tujuan Basyarnas}

Sehubungan dengan definisi arbitrase di atas terlihat bahwa dalam penyelesaian perselesihan melalui arbitrase terdapat pihak-pihak yang berselisih sebagai akibat hukum yang terjadi dalam bisnis dan industri. Di dalam perselisihan tersebut, mereka sepakat untuk menyelesaikan perselesihan mereka dengan menunjuk satu atau beberapa orang arbiter. Dengan demikian, asas-asas yang dapat dipetik dari perumusan definisi di atas adalah sebagai berikut: pertama, asas kesepakatan. Artinya kesepakatan para pihak untuk menyelesaikan perselisihan secara damai, seia sekata atau sepaham untuk menunjuk seorang atau beberapa orang arbiter. Kedua, asas

\footnotetext{
${ }^{7}$ Van der Tass, Kamus Hukum Belanda-Indonesia (Jakarta: Timun Mas, 1961), h. 17.

${ }^{8}$ Soekardono, Hukum Dagang Indonesia Jilid I (Bagian Kedua) (Jakarta: CV Rajawali, 1983), h. 9 .

${ }^{9}$ Sunaryati Hartono, Masalah Transnasional Dalam Penanaman Modal Asing (Bandung: Bina Cipta, 1972).
} 
musyawarah, yaitu setiap perselisihan diupayakan untuk diselesaikan secara musyawarah, baik antara arbiter dengan para pihak maupun antara arbiter itu sendiri. Ketiga, asas limitative, yaitu adanya pembatasan dalam penyelesaian perselisihan melalui arbitrase terbatas pada perselisihan-perselisihan di bidang perdagangan atau bsinis dan industry dan atau hak-hak pribadi yang dapat dikuasai sepenuhnya oleh para pihak. Keempat, asas final dan binding. Yaitu suatu putusan arbitrase bersifat putusan akhir yang tidak dapat dilanjutkan dengan upaya hokum lain, seperti banding atau kasasi. Asas ini pada prinsipnya memang sudah disepakati oleh para pihak dalam klausula atau perjanjian arbitrase mereka.

Sehubungan dengan asas tersebut, tujuan Badan Arbitrase Syari'ah Nasional itu sendiri adalah: pertama, menyelesaikan perselisihan/sengketa-sengketa keperdataan dengan prinsip mengutamakan usaha-usaha perdamaian (islah). Kedua, lahirnya Badan Arbitrase Syari'ah Nasional ini, menurut Prof. Mariam Darus Badrulzaman, sangat tepat karena melalui Badan Arbitrase tersebut, sengketasengketa bisnis yang operasionalnya menggunakan hukum Islam dapat diselesaikan dengan mempergunakan hukum Islam. ketiga, adanya Badan Arbitrase Syari'ah sebagai suatu lembaga permanen, berfungsi untuk menyelesaikan kemungkinan terjadinya sengketa perdata diantara bank-bank syariah dengan para nasabahnya atau pengguna jasa mereka pada khususnya dan antara sesama umat Islam yang melakukan hubungan-hubungan keperdataan yang menjadikan syariat Islam sebagai dasarnya pada umumnya adalah merupakan suatu kebutuhan yang sungguh-sungguh nyata. Keempat, Memberikan penyelesaian yang adil dan cepat dalam sengketasengketa muamalah atau perdata yang timbul dalam bidang perdagangan, industri, jasa dan lain-lain.

\section{PROSEDUR BERPERKARA MELALUI BASYARNAS}

\section{Lembaga Arbitrase}

Lembaga yang dimaksudkan di sini adalah suatu badan yang sengaja diadakan atau didirikan untuk menyelesaikan sengketa atau perselisihan. Menurut Pasal 1 angka 8 UU No. 30 Tahun 1999, Lembaga Arbitrase adalah badan yang dipilih oleh para pihak yang bersengketa atau yang ditunjuk oleh Pengadilan Negeri atau oleh 
Lembaga Arbitrase untuk memberikan putusan mengenai sengketa tertentu yang diserahkan penyelesaiannya melalui arbitrase.

Lembaga arbitrase dikenal ada dua yaitu Arbitrase Ad Hoc dan Arbitrase Institusional. Jenis lembaga Arbitrase Ad Hoc seringkali disebut arbitrase volenter, karena jenis lembaga arbitarse ini dibentuk khusus untuk menyelesaikan atau memutus perselesihan tertentu. Dengan demikian, kehadiran dan keberadaan arbitrase ad hoc hanya bersifat insidentil untuk menyelesaikan kasus tertentu dan keberadaannya hanya untuk satu kali penunjukkan, dalam arti selesai kasus diputus, lembaga tersebut akan bubar dengan sendirinya. Lembaga arbitrase institusional adalah lembaga atau badan arbitrase yang bersifat permanen, Pasal 1 ayat (2) Konvensi New York 1958 menyebut jenis lembaga ini adalah Permanent Arbitral Body. Ciri dari lembaga arbitrase institusional ini yang dapat pula dikatakan sebagai perbedaan antara lembaga ini dengan lembaga arbitrase ad hoc adalah sebagai berikut:

a. Arbitrase institusional didirikan untuk bersifat permanen atau selamanya, sedangkan arbitrase ad hoc sifatnya sementara dan akan bubar setelah perselesihan selesai diputus.

b. Arbitrase institusional sudah ada atau sudah berdiri sebelum suatu perselisihan timbul, sedangkan arbitarse ad hoc didirikan setelah perselisihan timbul oleh pihak yang bersangkutan.

c. Karena bersifat permanen atau selamanya, maka pendirian arbitrase institusional didirikan lengkap dengan susunan organisasi, tata cara pengangkatan arbiter dan tata cara pemeriksaan perselisihan yang pada umumnya tercantum dalam anggaran dasar pendirian lembaga tersebut, sedangkan arbitrase ad hoc tidak ada sama sekali.

Arbitrase institusional ini ada yang bersifat nasional dan ada pula yang bersifat internasional. Dikatakan bersifat nasional karena pendiriannya hanya untuk kepentingan bangsa dari Negara yang bersangkutan. Sedangkan dikatakan bersifat internasional karena merupakan pusat penyelesaian persengketaan antara pihak yang berbeda kewarganegaraannya. Beberapa lembaga arbitrase bersifat nasional, regional, dan internasional yang dikenal adalah:

a.Badan Arbitrase nasional Indonesia (BANI); 

b.Badan Arbitrase Muammalat Indonesia (BAMUI);
c. Asia-Africa legal Consultative Commite (AALCC);
d.The International Centre for Settlement of Invesment Disputes, dll. ${ }^{10}$

\section{Dasar Pertimbangan Memilih Basyarnas}

Secara umum dinyatakan bahwa lembaga arbitrase mempunyai kelebihan dibandingkan dengan lembaga peradilan. Kelebihan tersebut antara lain:

a.Di jamin kerahasiaan sengketa para pihak;

b.Dapat dihindarkan kelambatan yang diakibatkan hal prosedur dan administratif;

c.Para pihak dapat memilih arbiter yang menurut keyakinannya mempunyai pengetahuan, pengalaman, serta latar belakang yang cukup mengenai masalah yang disengketakan, jujur, dan adil;

d.Para pihak dapat menentukan pilihan hokum untuk menyelesaikan masalah serta proses dan tempat penyelenggaraan arbitrase; dan

e.Putusan arbitrase merupakan putusan yang mengikat para pihak dan dengan melalui tata cara (prosedur) sederhana saja ataupun langsung dapat dilaksanakan. ${ }^{11}$

Ada juga yang mengatakan bahwa beberapa alasan para pihak memilih penyelesaian sengketa melalui arbitrase dan tidak menggunakan peradilan umum, antara lain:

a.Kepercayaan dan keamanan bagi pihak yang berselisih. Arbitrase memberikan kebebasan dan otonomi yang sangat luas bagi pihak yang akan menyelesaikan persengketaan yang terjadi diantara mereka. Mereka dapat menentukan arbiter yang mereka inginkan atau menyerahkan sepenuhnya kepada lembaga arbitrase yang akan memilih arbiter bagi mereka. Disamping itu melalui arbitrase relatif lebih aman terhadap keadaan yang tidak menentu dan ketidakpastian sehubungan dengan sistem hukum yang berbeda;

${ }^{10}$ Sudiarto dan Zaeni Asyhadie, Mengenal Arbitrase (Salah Satu Alternatif Penyelesaian Sengketa Bisnis) (Jakarta: PT Rajagrafindo Persada, 2004), h. 49.

${ }^{11}$ Penjelasan Umum Undang-Undang No. 30 Tahun 1999 tentang Arbitrase dan Alternatif penyelesaian Sengketa Umum alinea keempat. 
b.Keahlian (expertise) dari para arbiter. Para pihak mempunyai kepercayaan yang besar kepada para arbiter mengenai perkara yang akan diselesaikan. Mereka juga dapat menunjuk arbiter yang memiliki keahlian tertentu untuk membantu menyelesaikan persengketaan mereka, sedangkan dalam pengadilan umum, hal ini tidak bisa dilakukan mereka.

c. Arbitrase bersifat rahasia. Arbitrase bersifat tertutup dan rahasia, karena ia hanya menyangkut pribadi dan tidak bersifat umum. Tujuannya adalah untuk melindungi para pihak dari hal-hal yang tidak diinginkan misalnya dengan penyebarnya rahasia bisnis para pihak yang bersengketa kepada masyarakat umum.

d.Non-preseden. Keputusan arbitrase tidak memiliki nilai yang berpengaruh penting dalam pengambilan keputusan arbitrase lainnya atau bersifat Nonpreseden. Dengan demikian keputusan arbitrase bisa saja berbeda antara satu dengan lainnya walaupun perkara yang diselesaikan serupa atau memiliki kesamaan.

e.Kearifan dan kepekaan arbiter. Kearifan dan kepekaan arbiter terhadap aturan yang akan diterapkan inilah yang menjadi motivasi para pihak yang bersengketa meminta penyelesaian sengketanya melalui arbitrase.

f. Keputusan arbitrase lebih mudah dilaksanakan daripada peradilan.

g.Cepat dan hemat biaya penyelesaian. Arbitrase lebih cepat dan lebih ringan biayanya dibandingkan pengadilan umum yang akan menyelesaian persengketaan yang terjadi antara para pihak. Melalui arbitrase tidak ada kemungkinan kasasi terhadap keputusan arbitrase, karena keputusannya final dan binding.

Menurut Erman Rajaguguk dengan mencermati pendapat para pakar, bahwa sebagian besar pengusaha lebih suka menyelesaikan sengketa yang timbul di antara mereka melalui arbitrase di luar negeri daripada pengadilan di Indonesia karena beberapa alasan berikut ini $^{12}$ : pertama, pengusaha asing lebih suka menyelesaikan

${ }^{12}$ Erman Rajaguguk, Arbitrase dalam Putusan Pengadilan (Jakarta: Chandra Pratama, 2000), h. 1-2. Di dalam beberapa literature perlu juga diketahui bahwa ada beberapa pertimbangan yang melandasi para pihak untuk memilih arbitrase sebagai upaya penyelesaian perselisihan mereka. Pertimbangan tersebut diantaranya: 1. Ketidakpercayaan para pihak pada Pengadilan Negeri; 2. Prosesnya cepat; 3. Dilakukan secara rahasia; 4. Bebas memilih arbiter (Pasal 13 (1) UU No. 30 Tahun 
sengketa melalui arbitrase di luar negeri karena menganggap sistem hukum dan pengadilan setempat asing bagi mereka. Sebenarnya alas an inipun tidak selalu benar karena mereka bias menunjuk pengacara setempat untuk mewakili mereka di depan pengadilan; kedua, pengusaha-pengusaha Negara maju beranggapan hakim-hakim Negara berkembang tidak menguasai sengketa-sengketa dagang yang melibatkan hubungan-hubungan niaga dan keuangan internasional yang rumit. Alasan ini juga sepenuhnya tidak benar karena hakim dapat memanggil saksi ahli; ketiga, pengusaha negara maju beranggapan penyelesaian sengketa melalui pengadilan akan memakan waktu yang lama dengan biaya yang besar karena proses pengadilan akan memakan waktu yang panjang dari tingkat pertama sampai tingkat Mahkamah Agung. Penyelesaian sengketa melalui arbitrase untuk beberapa kasus ternyata juga memakan waktu yang lama; keempat, keengganan pengusaha asing untuk menyelesaikan sengketa di depan pengadilan bertolak dari anggapan bahwa pengadilan akan bersikap subjektif kepada mereka karena sengketa diperiksan dan diadili bukan berdasarkan hukum mereka, oleh hakim yang bukan dari Negara mereka; kelima, penyelesaian sengketa di pengadilan akan mencari siapa yang salah dan siapa yang benar, dan hasilnya akan dapat merenggangkan hubungan dagang diantara mereka. Penyelesaian sengketa melalui arbitrase dianggap dapat melahirkan putusan yang kompromistis yang dapat diterima oleh kedua belah pihak yang bersengketa.

\section{Prosedur Berperkara Melalui Basyarnas ${ }^{13}$}

Mengenai prosedur berperkara di BASYARNAS telah diatur dengan sistematis sejak masih didirikan BAMUI. Secara garis besar aturan tersebut dituangkan dalam peraturan prosedur Badan Arbitrase Muamalat Indonesia (BAMUI) yang diberlakukan sejak 21 Oktober 1993. Beberapa tambahan yang terjadi hanya

1999 menyatakan: apabila tidak tercapai kesepakatan mengenai pemilihan arbiter atau tidak ada ketentuan mengenai pengangkatan arbiter, ketua Pengadilan Negeri dapat menunjuk arbiter atau majelis arbitrase.; 5. Diselesaikan oleh ahlinya (expert); 6. Merupakan putusan akhir (final0 dan mengikat (binding); 7. Biaya lebih murah; 8. Bebas memilih hukum yang diberlakukan; 9. Eksekusinya mudah; 10. Kepekaan arbiter; 11. Kecenderungan yang modern;

${ }^{13}$ Prosedur arbitrase beserta hal-hal yang perlu diperhatikan sesuai dengan ketentuan BAMUI, yakni: 1. Pengajuan Permohonan; 2. Perhitungan tenggang waktu; 3. Sikap BAMUI terhadap permohonan; 4. Penetapan Arbiter Tunggal atau Arbiter Majelis; 5. Sikap arbiter; 6. Arbiter yang meninggal; 7. Acara pemeriksaan; 8. Tempat kedudukan arbiter Tunggal atau Arbiter Majelis; 9. Tuntutan balasan; 10. Sikap arbiter terhadap termohon yang tidak datang; 11. Perdamaian; 12. Pembuktian dan saksi atau ahli; 13. Pencabutan permohonan; 14. Gugurnya hak membantah; 15. Pengambilan putusan. 
bersifat tehnis untuk menyempurnakan aturan yang telah ditetapkan sebelumnya. Sepanjang aturan tersebut tidak bertentangan dengan Undang-Undang No. 30 tahun 1999 tentang Arbitrase dan Alternatif Penyelesaian Sengketa. Adapun prosedur penyelesaian sengketa melalui BASYARNAS dimulai dengan penyerahan secara tertulis oleh para pihak yang sepakat untuk menyesaikan persengketaan melalui BASYARNAS sesuai dengan peraturan prosedur yang berlaku. Pihak yang bersengketa sepakat akan menyelesaikan persengketaan mereka dengan perdamaian (islah) tanpa ada suatu persengketaan berkenaan dengan perjanjian atas pemintaan para pihak tersebut. Kesepakatan ini dicantumkan dalam klausula arbitrase.

Prosedur arbitrase dimulai dengan didaftarkannya surat permohonan para pihak yang bersengketa oleh sekretaris. Berkas permohonan tersebut mesti mencantumkan alamat kantor atau tempat tinggal terakhir atau kantor dagang yang dinyatakan dengan tegas dalam klausula arbitrase. Berkas permohonan itu berisikan nama lengkap, tempat tinggal atau tempat kedudukan kedua belah pihak atau para pihak. Berkas juga memuat uraian singkat tentang duduknya sengketa dan juga apa yang dituntut. Pada dasarnya pengadilan negeri tidak berwenang untuk mengadili sengketa para pihak yang telah terikat dalam perjanjian arbitrase. Dengan adanya suatu perjanjian arbitrase tertulis, maka perjanjian itu meniadakan hak para pihak untuk mengajukan penyelesaian sengketa atau beda pendapat yang termuat dalam perjanjiannya ke Pengadilan Negeri. Dalam hal ini, Pengadilan Negeri menolak dan tidak akan campur tangan di dalam suatu penyelesaian sengketa yang telah ditetapkan melalui arbitrase, kecuali dalam hal-hal tertentu yang ditetapkan oleh undang-undang.

Surat perjanjian tertulis bahwa para pihak memilih penyelesaian sengketa melalui BASYARNAS, hendaklah ditandatangani oleh para pihak, di mana di dalam perjanjian tersebut disebutkan bahwa para pihak memilih penyelesaian sengketa melalui arbitrase syari'ah. Perjanjian itu harus dibuat dalam bentuk akta notaris. Para pihak boleh mengajukan tuntutan ingkar jika terdapat cukup bukti otentik yang menimbulkan keraguan bahwa arbiter yang ditunjuk akan melakukan tugasnya tidak secara bebas dan akan berpihak dalam mengambil keputusan. Usaha penyelesaian sengketa melalu mediator (arbiter) hendaklah memegang teguh kerahasiaan, dan dalam waktu paling lama 30 hari harus tercapai kesepakatan dalam bentuk tertulis yang ditandatangani oleh semua pihak yang terkait. Kesepakatan penyelesaian 
sengketa atau beda pendapat secara tertulis adalah final dan mengikat para pihak untuk dilaksanakan dengan itikad baik serta wajib didaftarkan di Pengadilan Negeri dalam waktu paling lama 30 (tiga puluh) hari sejak pendaftaran. Terhadap keputusan arbitrase, para pihak dapat mengajukan permohonan pembatalan apabila putusan tersebut diduga mengandung unsur-unsur sebagai berikut:

a.Surat dokumen yang diajukan dalam pemeriksaan setelah putusan dijatuhkan, diakui palsu atau dinyatakan palsu;

b.Setelah putusan diambil ditemukan dokumen yang bersifat menentukan, yang disembunyikan oleh pihak lawan; atau

c.Putusan diambil dari hasil tipu muslihat yang diakui oleh salah satu pihak dalam pemeriksaan sengketa.

Permohonan pembatalan tersebut harus diajukan secara tertulis ditujukan kepada Ketua Pengadilan Negeri, dalam waktu paling lama 30 hari terhitung sejak hari penyerahan dan pendaftaran putusan arbitrase kepada Panitera Pengadilan Negeri. Jika permohonan pembatalan tersebut dikabulkan, maka Ketua Pengadilan Negeri dalam waktu paling lama 30 hari sejak permohonan pembatalan diajukan, menjatuhkan putusan pembatalan. Dalam hal ini, para pihak dapat mengajukan permohonan banding ke Mahkamah Agung yang memutuskan dalam tingkat pertama dan terakhir. Mahkamah Agung juga hanya diberi waktu maksimal 30 hari untuk memutuskan permohonan banding tersebut. Mengenai biaya arbitrase ditentukan sendiri oleh arbiter, yang meliputi honorarium arbiter, biaya perjalanan dan biaya lain-lain yang dikeluarkan arbiter, biaya saksi dan atau saksi ahli yang diperlukan dalam pemeriksaan, dan biaya administrasi. Bahasa yang digunakan dalam proses arbitrase adalah bahasa Indonesia, kecuali atas persetujuan arbiter atau majelis arbitrase para pihak dapat memilih bahasa lain yang digunakan. Selanjutnya pada pihak atau kuasanya mempunyai hak dan kesempatan yang sama dalam mengemukakan pendapat masing-masing. Persyaratan untuk menjadi arbiter ${ }^{14}$, termasuk dalam hal ini arbiter syariah di BASYARNAS adalah:

\footnotetext{
${ }^{14}$ Sudiarto dan Zaeni Asyhadie, loc.cit., h. 82. Dalam kaitannya dengan pengangkatan arbiter, yang dapat ditunjuk atau diangkat sebagai arbiter harus memenuhi syarat-syarat cakap dalam melakukan tindakan hukum, yaitu: 1 . Berumur paling rendah 35 tahun; 2 . Tidak mempunyai hubungan keluarga sedarah atau semenda sampai derajat kedua dengan salah satu pihak yang bersengketa; 3 .
} 
a.Cakap melakukan tindakan hukum;

b.Berumur paling rendah 35 tahun;

c.Tidak punya hubungan keluarga sedarah atau semenda sampai dengan derajat kedua dengan salah satu pihak bersengketa;

d.Tidak mempunyai kepentingan finansial atau kepentingan lain atas putusan arbitrase;

e.Memiliki pengalaman serta menguasai secara aktif di bidangnya paling sedikit 15 tahun.

f. Bukan jaksa, hakim panitera dan pejabat peradilan lainnya.

Dalam hal para pihak tidak dapat memilih arbiter, maka Ketua Pengadilan Negeri atau Majelis arbitrase dapat menunjuk arbiter. Selanjutnya, arbiter atau majelis arbitrase dapat memerintahkan agar setiap dokumen atau bukti disertai dengan terjemahan ke dalam bahasa yang ditetapkan oleh arbiter atau majelis arbitrase. Arbiter atau majelis arbitrase dapat mendengar keterangan saksi atau mengadakan pertemuan yang dianggap perlu pada tempat tertentu di luar tempat arbitrase diadakan. Pemeriksaan saksi-saksi dan para saksi ahli di hadapan arbiter atau majelis arbitrase, diselenggarakan menurut ketentuan dalam hukum acara perdata. Para pihak menghadap arbiter pada hari yang telah ditentukan, dalam hal ini arbiter atau majelis arbitrase terlebih dahulu mengusahakan perdamaian antara para pihak yang bersengketa. Jika terwujud perdamaian, maka arbiter atau majelis arbitrase membuat suatu akta perdamaian yang final dan mengikat para pihak dan memerintahkan para pihak untuk memenuhi ketentuan perdamaian tersebut. Pemeriksaan terhadap pokok sengketa dilanjutkan apabila usaha perdamaian tidak berhasil. Selanjutnya para pihak diberi kesempatan terakhir kali untuk menjelaskan secara tertulis pendirian masingmasing serta mengajukan bukti yang dianggap perlu untuk menguatkan pendiriannya dalam jangka waktu yang ditetapkan oleh arbiter atau majelis arbitrase. Jika diperlukan dapat dimintakan penjelasan tambahan dari para pihak secara tertulis, dokumen atau bukti lainnya yang dianggap perlu dalam jangka waktu yang ditentukan oleh arbiter atau majelis arbitrase.

Tidak mempunyai kepentingan lain atas putusan arbitrase; 4. Memiliki pengalaman serta menuasai secara aktif di bidangnya paling sedikit lima belas tahun. (Pasal 12 ayat 1 UU No. 30 Tahun 1999). 
Pemeriksaan atas sengketa harus diselesaikan dalam waktu paling lama 180 hari sejak arbiter atau majelis arbitrase terbentuk. Jika diperlukan, maka jangka waktu ini dapat diperpanjang. Mengenai biaya pemanggilan dan perjalanan saksi atau saksi ahli dibebankan kepada pihak yang meminta. Apabila pemeriksaan sengketa telah selesai, pemeriksaan segera ditutup dan ditetapkan hari sidang untuk mengucapkan putusan arbitrase. Putusan diucapkan dalam waktu paling lama 30 hari setelah pemeriksaan ditutup. Selanjutnya dalam waktu 14 hari9 setelah putusan diterima, para pihak dapat mengajukan kepada arbiter atau majelis arbitrase untuk melakukan koreksi terhadap kekeliruan administratif dan atau menambah atau mengurangi sesuatu tuntutan putusan. Adapun menkanisme operasional BASYARNAS mempunyai prosedur atau mekanisme operasional yang memuat ketentuan-ketentuan antara lain:
a. Permohonan untuk mengadakan arbitrase,
b. Penetapan Arbiter,
c. Acara Pemeriksaan,
d. Perdamaian,
e. Pembuktian dan saksi atau ahli,
f. Berakhirnya Pemeriksaan,
g. Pengambilan Putusan,
h. Perbaikan Putusan,
i. Pembatalan Putusan,
j. Pendaftaran Putusan,
k. Pelaksanaan Putusan,
1. Biaya Arbitrase.

\section{PENUTUP}

1. Bahwa keberadaan BASYARNAS sebagai badan yang berwenang menyelesaikan sengketa bisnis syari'ah memiliki peranan yang sangat penting, diantaranya adalah: menyelesaikan perselisihan/sengketa-sengketa keperdataan dengan prinsip mengutamakan usaha-usaha perdamaian (islah); menyelesaikan sengketa-sengketa bisnis yang operasionalnya menggunakan hukum Islam dapat diselesaikan dengan mempergunakan hukum Islam; menyelesaikan kemungkinan terjadinya sengketa 
perdata diantara bank-bank syari'ah dengan para nasabahnya atau pengguna jasa mereka pada khususnya dan antara sesama umat Islam yang melakukan hubunganhubungan keperdataan yang menjadikan syari'at Islam sebagai dasarnya pada umumnya adalah merupakan suatu kebutuhan yang sungguh-sungguh nyata; dan memberikan penyelesaian yang adil dan cepat dalam sengketa-sengketa muamalah atau perdata yang timbul dalam bidang perdagangan, industri, jasa dan lain-lain.

2. Bahwa kelebihan BASYARNAS diantaranya adalah: adanya kepercayaan dan keamanan bagi pihak yang berselisih; keahlian (expertise) dari para arbiter; arbitrase bersifat rahasia; Non-preseden (keputusan arbitrase tidak memiliki nilai yang berpengaruh penting dalam pengambilan keputusan arbitrase lainnya atau bersifat Non-preseden. Dengan demikian keputusan arbitrase bisa saja berbeda antara satu dengan lainnya walaupun perkara yang diselesaikan serupa atau memiliki kesamaan); kearifan dan kepekaan arbiter; keputusan arbitrase lebih mudah dilaksanakan daripada peradilan; cepat dan hemat biaya penyelesaian.

3. Bahwa prosedur BASYARNAS dalam menyelesaikan perkara yaitu: permohonan untuk mengadakan arbitrase; Penetapan Arbiter; acara pemeriksaan; perdamaian; pembuktian dan saksi atau ahli; berakhirnya pemeriksaan; pengambilan putusan; perbaikan putusan; pembatalan putusan; pendaftaran putusan; pelaksanaan putusan; dan biaya arbitrase.

\section{DAFTAR PUSTAKA}

Abdurrasyid, Priyatna. Penyelesaian Sengketa Komersial (Nasional dan InternasionalO di Luar Pengadilan, Makalah, September 1996.

BAMUI. Badan Arbitrase Muammalat Indonesia. Jakarta: BAMUI, 1994.

Coulson, N.J. A History of Islamic Law. New York: Edinberg University Press, 1991.

Elkoury, Frank dan Elkoury, Edna. How Arbitration Work, Washington DS., 1974, dikutip dari M. Husseyn dan A. Supriyani Kardono, Kertas Kerja Hukum Ekonomi, Hukum dan Lembaga Arbitrase di Indonesia. Jakarta: Proyek Pengembangan Hukum Ekonomi dan penyempurnaan Sistem Pengadaan, Kantor Menteri Negara Koordinasi Bidang Ekonomi, Keuangan dan Pengawasan Pengembangan, 1995.

Hartono, Sunaryati. Masalah Transnasional Dalam Penanaman Modal Asing. Bandung: Bina Cipta, 1972. 
Penjelasan Umum Undang-Undang No. 30 Tahun 1999 tentang Arbitrase dan Alternatif penyelesaian Sengketa Umum alinea keempat.

Poerwosutjipto, H.M.N. Pokok-Pokok Hukum Dagang, Perwasitan, Kepailitan dan Penundaan Pembayaran Cet. III. Jakarta: Djambatan, 1992.

Rajaguguk, Erman. Arbitrase dalam Putusan Pengadilan. Jakarta: Chandra Pratama, 2000 .

Soekardono. Hukum Dagang Indonesia Jilid I Bagian Kedua. Jakarta: CV Rajawali, 1983.

Subekti. Arbitrase Perdagangan. Bandung: Bina Cipta, 1992.

Sudiarto dan Asyhadie, Zaeni. Mengenal Arbitrase (Salah Satu Alternatif Penyelesaian Sengketa Bisnis). Jakarta: PT Rajagrafindo Persada, 2004.

Tass, Van der. Kamus Hukum Belanda-Indonesia. Jakarta: Timun Mas, 1961 